\title{
EVALUASI PROGRAM BANTUAN DANA BERGULIR PADA EMPAT KOPERASI PENERIMA PROGRAM BANTUAN DANA BERGULIR DI KABUPATEN BULELENG TAHUN 2014
}

\author{
I Ketut Adi Widiana \\ Jurusan Pendidikan Ekonomi, Fakultas Ekonomi \\ Universitas Pendidikan Ganesha Singaraja, \\ Indonesia
}

e-mail: adiwidiana95@gmail.com

\begin{abstract}
ABSTRAK
Penelitian ini bertujuan untuk mengetahui evaluasi dari program bantuan dana bergulir pada empat koperasi penerima program bantuan dana bergulir di Kabupaten Buleleng Tahun 2014 ditinjau dari segi context, input, process, and product. Jenis penelitian ini merupakan penelitian studi evaluatif dengan menggunakan model CIPP. Subjek dalam penelitian ini adalah pengurus koperasi penerima program bantuan dana bergulir di Kabupaten Buleleng Tahun 2014 yang berjumalh 20 pengurus koperasi dan objek dalam penelitian ini adalah evaluasi program bantuan dana bergulir pada koperasi. Data dikumpulkan dengan menggunakan metode kuesioner dan dianalisis secara kuantitatif dengan menggunakan statistik deskriptif. Untuk menentukan kualitas program, data terlebih dahulu dianalisis menggunakan skor standar atau Z-score yang selanjutnya ditransformasikan kedalam $T$-score kemudian diverifikasi ke dalam prototype Glickman. Hasil penelitian ini menunjukkan bahwa evaluasi program bantuan dana bergulir pada empat koperasi penerima program bantuan dana bergulir di Kabupaten Buleleng Tahun 2014 berada pada kriteria efektif $(++++)$. Artinya pada dimensi context efektif, pada dimensi input efektif, pada dimensi process efektif, dan pada dimensi product efektif.
\end{abstract}

Kata kunci : Bantuan Dana Bergulir, Evaluasi Program, Model CIPP

\begin{abstract}
This study aims to know the evaluation of revolving fund programs in the four cooperative recipient of revolving funds program in Buleleng Regency at Year 2014 in terms of context, input, process, and product. This type of study is an evaluative research study using a model of CIPP. Subjects in this study are the cooperative management of program's recipients revolving funds in Buleleng Regency at year 2014, amounting to 20 cooperative managements and the object in this study is the evaluation of revolving funds programs in the cooperative. Data were collected using a questionnaire and analyzed quantitatively by using descriptive statistics. To determine the quality of the program, first data was analyzed using standard score or Z-score is subsequently transformed into T-score were then verified in the prototype Glickman. The results of this study indicate that evaluation of revolving fund programs in the four cooperative recipient revolving funds program in Buleleng regency at year 2014 were on the criterion of effective $(++++)$. That is the effective context dimension, the dimension of the effective input, the dimensions of an effective process, and the dimensions of an effective product.
\end{abstract}

Keywords : Assistance Revolving Fund, Program Evaluation, CIPP Model 


\section{PENDAHULUAN}

Koperasi berasal dari dua suku kata yaitu Co dan Operation, yang mengandung arti kerjasama untuk mencapai tujuan tertentu. Menurut Undang-undang No. 25 tahun 1992 tentang perkoperasian dikatakan definisi koperasi adalah sebagai badan usaha yang beranggotakan orang seorang atau badan hukum koperasi dengan melandaskan kegiatannya berdasarkan prinsip-prinsip koperasi sekaligus sebagai gerakan ekonomi rakyat yang berdasarkan atas asas kekeluargaan. Dalam upaya melandaskan seluruh kegiatannya, koperasi seringkali mengalami berbagai hambatan, salah satunya yaitu masalah lemahnya koperasi untuk memperoleh akses permodalan dari perbankan. Sebagian dari pihak perbankan menganggap bahwa koperasi memiliki resiko yang sangat tinggi, tidak profitable dan kurang memiliki jaminan. Selain itu, perbankan yang memberikan akses pinjaman modal menawarkan bunga yang tinggi sehingga koperasi mengalami kesulitan dalam akses permodalan dan menjadi hambatan dalam tumbuh berkembangnya sebuah koperasi.

Permasalahan modal yang dihadapi oleh koperasi tersebut, kini telah mendapatkan bantuan dari pemerintah. Untuk mendukung upaya tersebut dalam hal ini pemerintah membuat program penguatan permodalan bagi koperasi dengan nama program bantuan dana bergulir. Program bantuan dana bergulir adalah dana pemerintahan yang berasal dari Anggaran Pendapatan dan Belanja Negara (APBN) yang disalurkan dalam bentuk pinjaman kepada koperasi dalam jangka waktu tertentu untuk memenuhi kebutuhan permodalan anggotanya yang bergerak di berbagai usaha produktif, dan selanjutnya digulirkan kepada koperasi lainnya. Seperti program-program lainnya yang telah dijalankan oleh pemerintah, program dana bergulir juga memiliki tujuan yaitu memberdayakan usaha mikro melalui perkuatan permodalan
Koperasi Simpan Pinjam (KSP) atau Unit Simpan Pinjam (USP) koperasi, meningkatkan kemampuan sumberdaya manusia dalam bidang manajemen usaha dan pengelolaan keuangan serta memperkuat peran dan posisi KSP atau USP koperasi dalam mendukung upaya perluasan kesempatan kerja dan pengentasan kemiskinan.

Kabupaten Buleleng merupakan salah satu kabupaten yang mendapatkan program bantuan dana bergulir pada koperasi. Melalui Dinas Koperasi, Perdagangan dan Perindustrian Kabupaten Buleleng, tercatat pada tahun 2014 dana sebesar Rp 2.850.000.000,00 sudah digelontorkan kepada empat koperasi terpilih penerima program bantuan dana bergulir yang sebelumnya telah melalui proses seleksi dari Lembaga Pengelola Dana Bergulir (LPDB). Koperasi yang mendapatkan program bantuan dana bergulir pada Tahun 2014 adalah KUD Dharma Prawerti dengan bantuan dana sebesar Rp 1.000.000.000,00, KUD Karma Bumi Amertha dengan bantuan dana sebesar Rp 1.000.000.000,00 kemudian KSU Cipta Dharma Sejahtera dengan bantuan dana sebesar $\mathrm{Rp}$ 350.000.000,00 dan KUD Tirta Luhur dengan bantuan dana sebesar $\mathrm{Rp}$ $500.000 .000,00$ dengan total keseluruhan bantuan dana bergulir pada tahun 2014 adalah sebesar Rp 2.850.000.000,00. Dana bergulir tersebut dikelola dan dimanfaatkan oleh koperasi untuk seluruh kegiatan yang dilakukan dari masing-masing koperasi, akan tetapi dalam pelaksanaannya koperasi penerima program mengalami beberapa permasalahan yaitu (1) bantuan dana yang diberikan oleh pemerintah kepada koperasi tidak sepenuhnya mencukupi kebutuhan koperasi sehingga koperasi harus meminjam kembali dana kepada pihak lain, (2) kurangnya pengawasan dari pemerintah terhadap program bantuan dana yang diberikan kepada koperasi mengakibatkan kurangnya transparansi keuangan dalam pelaporan pertanggungjawaban. 
Melihat dari besarnya jumlah bantuan dana yang telah disalurkan serta permasalahan yang dihadapi oleh koperasi penerima program bantuan dana bergulir, maka perlu kiranya dilakukan sebuah evaluasi. Menurut Cross (dalamSukardi, 2008:1) evaluasi adalah "proses yang menentukan kondisi, dimana suatu tujuan telah dapat dicapai". Pengertian ini menunjukan adanya hubungan langsung antara evaluasi dengan tujuan yang akan dicapai. Anderson (dalam Arikunto,2004) memandang evaluasi sebagai sebuah proses menentukan hasil yang telah dicapai beberapa kegiatan yang direncanakan untuk mendukung tercapainya tujuan. Untuk mengetahui tingkat keefektivitasan sebuah program maka perlu dilakukan sebuah evaluasi lebih mendalam apakah koperasi tersebut telah mampu untuk mengelola bantuan dana yang telah diberikan oleh pemerintah dengan baik sehingga apa yang menjadi tujuan dari program tersebut dapat tercapai dengan baik. Menurut Arikunto (2004) Evaluasi program merupakan upaya untuk mengetahui efektivitas komponen program dalam mendukung pencapaian tujuan program. Evaluasi dilakukan secara sistematis dan objektif dengan tujuan untuk mengkaji proses dan hasil dari suatu kegiatan/program/kebijakan yang telah dilaksanakan.

Ada beberapa model evaluasi yang populer dan banyak dipakai sebagai strategi atau pedoman kerja pelaksanaan evaluasi program, namun pada penelitian ini digunakan model evaluasi program CIPP, karena sangat berkaitan dengan jenis evaluasi pelaksanaan program ini. Model CIPP dikembangkan oleh Stufflebeam dan kawan-kawan (dalam Arikunto dan Cepi, 2004:29) di Ohio State University yang merupakan sebuah singkatan dari huruf awal empat buah kata, yaitu: (1) context evaluation: evaluasi terhadap konteks, (2) input evaluation: evaluasi terhadap masukan, (3) process evaluation: evaluasi terhadap proses, dan (4) product evaluation: evaluasi terhadap hasil.
Adapun penelitian ini bertujuan untuk mengetahui (1) evaluasi dari program bantuan dana bergulir pada empat koperasi penerima program bantuan dana bergulir di Kabupaten Buleleng Tahun 2014 ditinjau dari segi contect, (2) evaluasi dari program bantuan dana bergulir pada empat koperasi penerima program bantuan dana bergulir di Kabupaten Buleleng Tahun 2014 ditinjau dari segi input, (3) evaluasi dari program bantuan dana bergulir pada empat koperasi penerima program bantuan dana bergulir di Kabupaten Buleleng Tahun 2014 ditinjau dari segi process, dan (4) evaluasi dari program bantuan dana bergulir pada empat koperasi penerima program bantuan dana bergulir di Kabupaten Buleleng Tahun 2014 ditinjau dari segi product.

\section{METODE}

Pengumpulan data dilakukan dengan metode kuesioner. Kuesioner dalam penelitian ini disebarkan kepada pengurus koperasi penerima program bantuan dana bergulir di Kabupaten Buleleng Tahun 2014. Sumber data yang digunakan dalam penelitian ini berupa data primer dan data sekunder. Data primer dalam penelitian ini yaitu skor hasil kuesioner tentang evaluasi program bantuan dana bergulir yang diperoleh melalui penyebaran kuesioner yang diberikan kepada masing-masing pengurus dari empat koperasi penerima program bantuan dana bergulir di Kabupaten Buleleng Tahun 2014 yang berjumlah 20 orang pengurus koperasi. Data sekunder dalam penelitian ini yaitu data mengenai nama-nama koperasi dan pengurus koperasi penerima program bantuan dana bergulir di Kabupaten Buleleng Tahun 2014. Data dalam penelitian ini dianalisis secara kuantitatif dengan menggunakan statistik deskriptif. Untuk menentukan kualitas program, data terlebih dahulu dianalisis menggunakan skor standar atau Z-score yang selanjutnya ditransformasikan kedalam $T$-score kemudian diverifikasi kedalam prototype Glickman. 
HASIL DAN PEMBAHASAN Hasil

1) Evaluasi program bantuan dana bergulir pada empat koperasi penerima program bantuan dana bergulir di Kabupaten Buleleng Tahun 2014 ditinjau dari segi context.

Evaluasi program bantuan dana bergulir, pada dimensi context dapat diukur dengan lima indikator seperti indikator kebijakan terkait dengan program, tujuan program, kebutuhan, harapan, dan peluang pengembangan diri. Untuk memberikan gambaran yang lebih jelas untuk masing-masing indikator pada dimensi context, terlebih dahulu dapat diverifikasi hasil perhitungan analisis data tehadap masing-masing indikator pada dimensi context. Setelah data mentah masingmasing indikator ditransformasikan ke dalam T-skor dapat diikthisarkan dalam Tabel 11 berikut.

Tabel 1 Rekapitulasi Hasil Perhitungan Dimensi Context untuk Masing-Masing Indikator

\begin{tabular}{clccccc}
\hline \multirow{2}{*}{ No } & \multicolumn{1}{c}{ Indikator } & \multicolumn{3}{c}{ Frekuensi } & Keterangan \\
\cline { 3 - 5 } & & $\mathrm{f}+$ & $\mathrm{f}-$ & Hasil & \\
\hline 1 & Kebijakan terkait dengan program & 12 & 8 & + & Positif \\
2 & Tujuan program & 12 & 8 & + & Positif \\
3 & Kebutuhan & 5 & 15 & - & Negatif \\
4 & Harapan & 12 & 8 & + & Positif \\
5 & Peluang pengembangan diri & 12 & 8 & + & Positif \\
\hline \multicolumn{1}{r}{ Hasil } & & & + & Positif \\
\hline
\end{tabular}

Berdasarkan Tabel 1 di atas, dari

lima indikator yang dipakai untuk mengukur dimensi context tampak bahwa empat indikator sudah dapat mendukung berlangsungnya program bantuan dana bergulir yang diberikan oleh pemerintah seperti pada indikator kebijakan terkait dengan program, tujuan program, harapan dan peluang pengembangan diri. Untuk Indikator kebutuhan belum mendukung keberhasilan program bantuan dana bergulir karena hasilnya negatif yaitu pada frekuensi skor $f(+)=5$ lebih kecil daripada frekuensi skor standar $f(-)=$ 15.

Untuk menjawab rumusan masalah pertama, dapat diverifikasi dari hasil perhitungan analisis data terhadap dimensi context. Setelah data dimensi context ditransformasikan ke dalam Tskor dapat diikhtisarkan dalam Tabel 2 berikut.

Tabel 2 Rekapitulasi Hasil Perhitungan Dimensi Context

\begin{tabular}{ccccc}
\hline Dimensi & \multicolumn{3}{c}{ Frekuensi } & \multirow{2}{*}{ Keterangan } \\
\cline { 2 - 5 } & $\mathrm{f}+$ & $\mathrm{f}-\mathrm{H}$ & Hasil & \\
\hline Context & 15 & 5 & + & Positif \\
\hline & Hasil & & + & Positif \\
\hline
\end{tabular}

Berdasarkan Tabel 2 di atas tampak bahwa pada dimensi context, menunjukkan hasil $\sum f(+)=15>\sum f(-)$ $=5$, atau menghasilkan + (efektif). Dengan demikian, dapat dinyatakan bahwa pada dimensi konteks evaluasi program bantuan dana bergulir pada empat koperasi penerima program bantuan dana bergulir di Kabupaten Buleleng Tahun 2014 tergolong efektif.
2) Evaluasi program bantuan dana bergulir pada empat koperasi penerima program bantuan dana bergulir di Kabupaten Buleleng Tahun 2014 ditinjau dari segi input.

Evaluasi program bantuan dana bergulir, pada dimensi input dapat diukur dengan enam indikator seperti indikator sumber daya manusia, sosialisasi, manajemen, sarana prasarana, petunjuk pelaksanaan dan 
dana operasional. Untuk memberikan gambaran yang lebih jelas untuk masing-masing indikator pada dimensi input, terlebih dahulu dapat diverifikasi hasil perhitungan analisis data tehadap masing-masing indikator pada dimensi input. Setelah data mentah masingmasing indikator ditransformasikan ke dalam T-skor dapat diikthisarkan dalam Tabel 3 berikut.

Tabel 3 Rekapitulasi Hasil Perhitungan Dimensi Input untuk Masing-Masing Indikator

\begin{tabular}{|c|c|c|c|c|c|}
\hline \multirow[t]{2}{*}{ No } & \multirow[t]{2}{*}{ Indikator } & \multicolumn{3}{|c|}{ Frekuensi. } & \multirow[t]{2}{*}{ Keterangan } \\
\hline & & $f+$ & $f-$ & Hasil & \\
\hline 1 & Sumber daya manusia & 11 & 9 & + & Positif \\
\hline 2 & Sosialisasi & 11 & 9 & + & Positif \\
\hline 3 & Manajemen & 13 & 7 & + & Positif \\
\hline 4 & Sarana prasarana & 15 & 5 & + & Positif \\
\hline 5 & Petunjuk pelaksanaan & 11 & 9 & + & Positif \\
\hline 6 & Dana operasional & 8 & 12 & - & Negatif \\
\hline
\end{tabular}

Berdasarkan Tabel 3 di atas, dari enam indikator yang dipakai untuk mengukur dimensi input tampak bahwa lima indikator sudah dapat mendukung berlangsungnya program bantuan dana bergulir yang diberikan oleh pemerintah seperti pada indikator sumber daya manusia, sosialisasi, manajemen, sarana prasarana, dan petunjuk pelaksanaan. Untuk indikator dana operasional belum mendukung keberhasilan program bantuan dana bergulir karena hasilnya negatif yaitu pada frekuensi skor $f(+)=8$ lebih kecil daripada frekuensi skor standar $f(-)=$ 12.

Untuk menjawab rumusan masalah kedua, dapat diverifikasi dari hasil perhitungan analisis data terhadap dimensi input. Setelah data dimensi input ditransformasikan ke dalam T-skor dapat diikhtisarkan dalam Tabel 4 berikut.

Tabel 4 Rekapitulasi Hasil Perhitungan Dimensi Input

\begin{tabular}{ccccc}
\hline Dimensi & \multicolumn{1}{c}{ Frekuensi } & Keterangan \\
\cline { 2 - 5 } & $f+$ & $f-$ & Hasil & Positif \\
\hline Input & 11 & 9 & + & Positif \\
\hline
\end{tabular}

Berdasarkan Tabel 4 di atas tampak bahwa pada dimensi input, menunjukkan hasil $\sum f(+)=11>\sum f(-)$ $=9$, atau menghasilkan + (efektif). Dengan demikian, dapat dinyatakan bahwa pada dimensi input evaluasi program bantuan dana bergulir pada pada empat koperasi penerima program bantuan dana bergulir di Kabupaten Buleleng Tahun 2014 tergolong efektif.

3) evaluasi program bantuan dana bergulir pada empat koperasi penerima program bantuan dana bergulir di Kabupaten Buleleng Tahun 2014 ditinjau dari segi process.
Evaluasi program bantuan dana bergulir, pada dimensi process dapat diukur dengan enam indikator seperti indikator perencanaan program, proses seleksi program, penyaluran dana, pemanfaatan dana, pengembalian dana, dan monitoring. Untuk memberikan gambaran yang lebih jelas untuk masing-masing indikator pada dimensi process, terlebih dahulu dapat diverifikasi hasil perhitungan analisis data tehadap masing-masing indikator. Setelah data mentah masing-masing indikator ditransformasikan ke dalam Tskor dapat diikthisarkan dalam Tabel 5 berikut. 
Tabel 5 Rekapitulasi Hasil Perhitungan Dimensi Process untuk Masing-Masing Indikator

\begin{tabular}{llcccc}
\hline No & Indikator & \multicolumn{3}{c}{ Frekuensi } & Keterangan \\
\cline { 3 - 5 } & & 13 & $f-$ & Hasil & \\
\hline 1 & Perencanaan program & 13 & 7 & + & Positif \\
2 & Proses seleksi program & 14 & 6 & + & Positif \\
3 & Penyaluran dana & 11 & 9 & + & Positif \\
4 & Pemanfaatan dana & 12 & 8 & + & Positif \\
5 & Pengembalian dana & 8 & 12 & - & Positif \\
6 & Monitoring & & & + & Pegatif \\
\hline & Hasil & & & + & Positif \\
\hline
\end{tabular}

Berdasarkan Tabel 5 di atas, dari enam indikator yang dipakai untuk mengukur dimensi process tampak bahwa lima indikator sudah dapat mendukung berlangsungnya program bantuan dana bergulir yang diberikan oleh pemerintah seperti indikator perencanaan program, proses seleksi program, penyaluran dana, pemanfaatan dana, dan pengembalian dana. Untuk indikator monitoring belum mendukung keberhasilan program bantuan dana bergulir karena hasilnya negatif yaitu pada frekuensi skor $\mathrm{f}(+)=$ 8 lebih kecil daripada frekuensi skor standar $f(-)=12$.

Untuk menjawab rumusan masalah ketiga, dapat diverifikasi dari hasil perhitungan analisis data terhadap dimensi process. Setelah data dimensi proses ditransformasikan ke dalam $\mathrm{T}$ skor dapat diikhtisarkan dalam Tabel 6 berikut.

Tabel 6 Rekapitulasi Hasil Perhitungan Dimensi Process

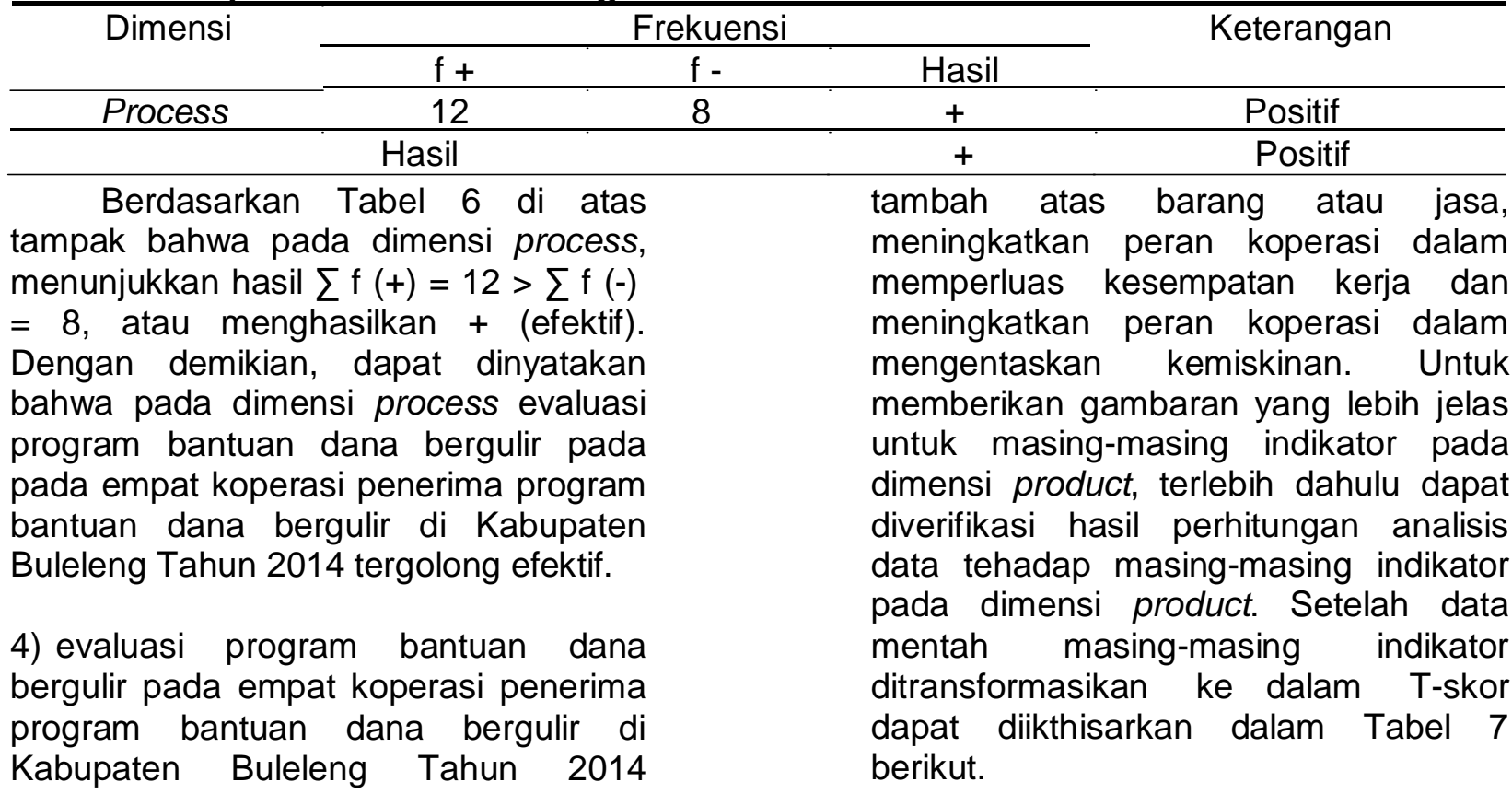
ditinjau dari segi product.

Evaluasi program bantuan dana bergulir, pada dimensi product dapat diukur dengan empat indikator seperti indikator meningkatkan kemampuan koperasi dalam mengakses sumber pendanaan, meningkatkan kemampuan koperasi dalam menciptakan nilai 
Tabel 7 Rekapitulasi Hasil Perhitungan Dimensi Product untuk Masing-Masing Indikator

\begin{tabular}{|c|c|c|c|c|c|}
\hline \multirow[t]{2}{*}{ No } & \multirow[t]{2}{*}{ Indikator } & \multicolumn{3}{|c|}{ Frekuensi } & Keterangan \\
\hline & & $f+$ & $f-$ & Hasil & \\
\hline 1 & $\begin{array}{l}\text { Meningkatkan kemampuan koperasi dalam } \\
\text { mengakses sumber pendanaan. }\end{array}$ & 12 & 8 & + & Positif \\
\hline 2 & $\begin{array}{l}\text { Meningkatkan kemampuan koperasi dalam } \\
\text { menciptakan nilai tambah atas barang atau jasa. }\end{array}$ & 12 & 8 & + & Positif \\
\hline 3 & $\begin{array}{l}\text { Meningkatkan peran koperasi dalam } \\
\text { memperluas kesempatan kerja. }\end{array}$ & 15 & 5 & + & Positif \\
\hline \multirow[t]{2}{*}{4} & $\begin{array}{l}\text { Meningkatkan peran koperasi dalam } \\
\text { mengentaskan kemiskinan. }\end{array}$ & 15 & 5 & + & Positif \\
\hline & Hasil & & & + & Positif \\
\hline $\begin{array}{l}\text { emp } \\
\text { men } \\
\text { bahy } \\
\text { men } \\
\text { bant } \\
\text { oleh } \\
\text { pene } \\
\text { berg } \\
2014 \\
\text { men } \\
\text { dalar } \\
\text { men }\end{array}$ & $\begin{array}{l}\text { Berdasarkan Tabel } 7 \text { di atas, dari } \\
\text { at indikator yang dipakai untuk } \\
\text { yukur dimensi product tampak } \\
\text { la semua indikator sudah dapat } \\
\text { dukung berlangsungnya program } \\
\text { lan dana bergulir yang diberikan } \\
\text { pemerintah kepada empat koperasi } \\
\text { rima program bantuan dana } \\
\text { ulir di Kabupaten Buleleng Tahun } \\
\text { seperti pada indikator } \\
\text { ngkatkan kemampuan koperasi } \\
\text { n mengakses sumber pendanaan, } \\
\text { ngkatkan kemampuan koperasi }\end{array}$ & \multicolumn{4}{|c|}{$\begin{array}{l}\text { dalam menciptakan nilai tambah atas } \\
\text { barang atau jasa, meningkatkan peran } \\
\text { koperasi dalam memperluas } \\
\text { kesempatan kerja, dan meningkatkan } \\
\text { peran koperasi dalam mengentaskan } \\
\text { kemiskinan. } \\
\text { Untuk menjawab rumusan } \\
\text { masalah keempat, dapat diverifikasi dari } \\
\text { hasil perhitungan analisis data terhadap } \\
\text { dimensi product. Setelah data dimensi } \\
\text { produk ditransformasikan ke dalam T- } \\
\text { skor dapat diikhtisarkan dalam Tabel } 8 \\
\text { berikut. }\end{array}$} \\
\hline
\end{tabular}

Tabel 8 Rekapitulasi Hasil Perhitungan Dimensi Product

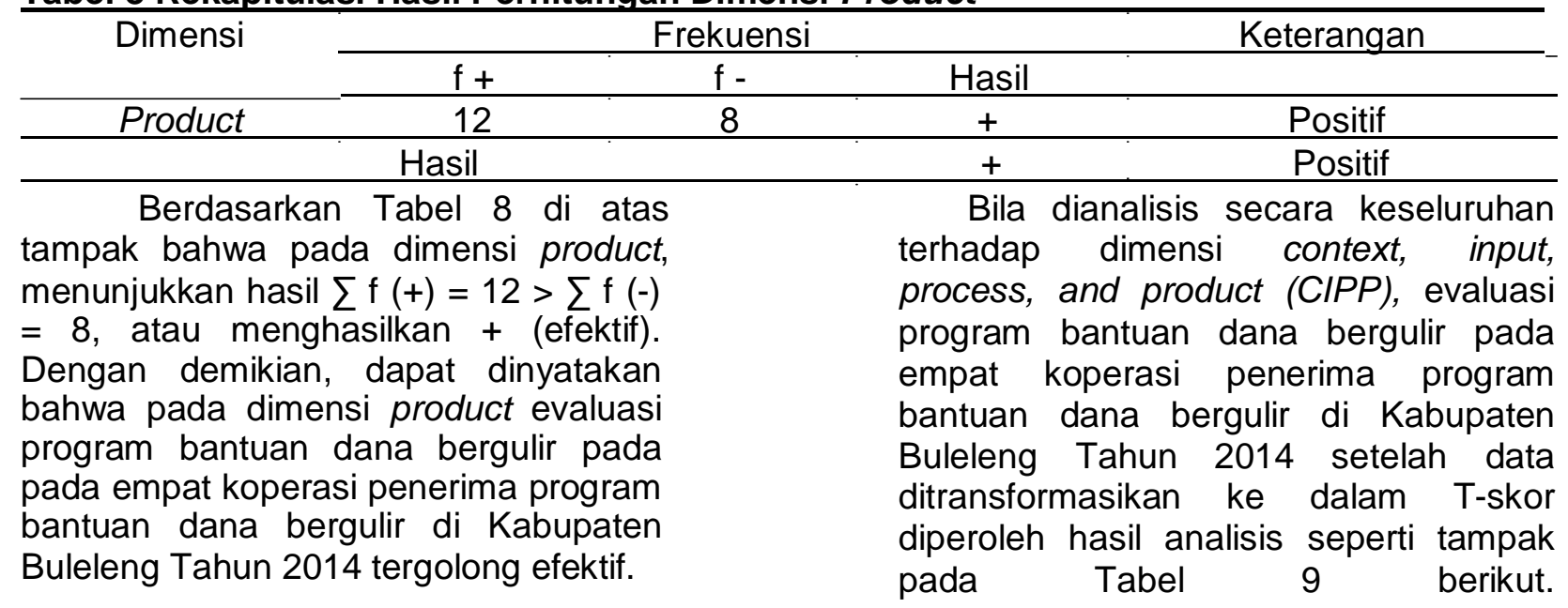

Tabel 9 Rekapitulasi Hasil Perhitungan Dimensi CIPP Secara Bersamaan

\begin{tabular}{lllcccc}
\hline No & & Dimensi & \multicolumn{3}{c}{ Frekuensi } & Keterangan \\
\cline { 3 - 5 } & & $f+$ & $f-$ & Hasil & \\
\hline 1 & Context & 15 & 5 & + & Positif \\
2 & Input & 11 & 9 & + & Positif \\
3 & Process & 12 & 8 & + & Positif \\
4 & Product & 12 & 8 & + & Positif \\
\hline & & & & + & Positif \\
\hline
\end{tabular}


Berdasarkan Tabel 9 di atas tampak bahwa pada dimensi context, $\Sigma$ $f(+)>\sum f(-)$ atau menghasilkan + (efektif), ini disebabkan karena sebagian besar komponen indikator pada dimensi context dapat mendukung program bantuan dana bergulir. Dimensi input, $\Sigma$ $f(+)>\Sigma f(-)$ atau menghasilkan + (efektif), ini disebabkan karena sebagian besar komponen indikator pada dimensi input dapat mendukung program bantuan dana bergulir. Dimensi process, $\sum f(+)>\sum f(-)$ atau menghasilkan + (efektif) ini disebabkan karena sebagian besar komponen indikator pada dimensi process dapat mendukung program bantuan dana bergulir. Pada dimensi product, $\sum \mathrm{f}(+)>\sum \mathrm{f}(-)$ atau menghasilkan + (efektif), ini disebabkan karena komponen indikator pada dimensi product telah dapat mendukung program bantuan dana bergulir. Jadi secara keseluruhan menghasilkan $(++$ ++ ).

Untuk melihat evaluasi program bantuan dana bergulir pada empat koperasi penerima program bantuan dana bergulir di Kabupaten Buleleng Tahun 2014, data yang diperoleh pada Tabel 9 di atas dapat dianalisis dengan memverifikasi ke dalam kuadran berikut.

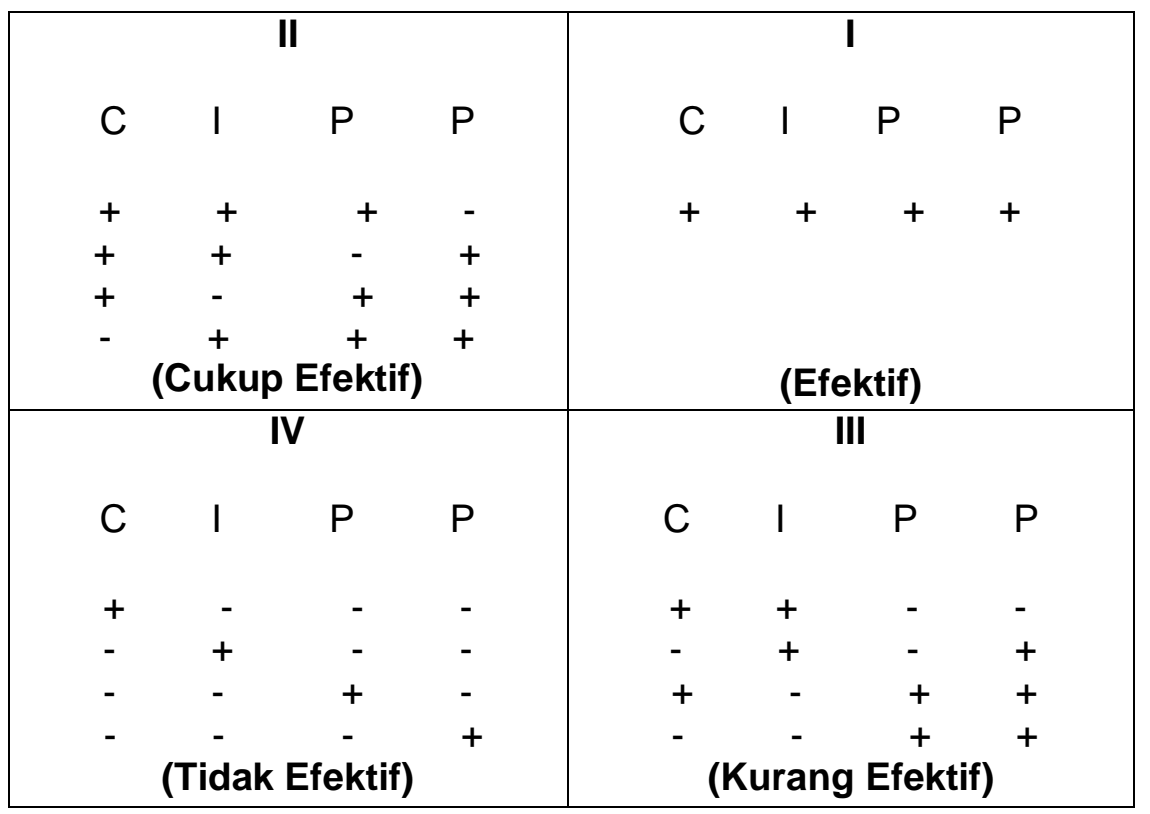

Gambar 1 Prototype Evaluasi Program Bantuan Dana Bergulir diadaptasi dari teori Glickman

Dari perolehan hasil perhitungan seperti tampak pada Gambar 1 di atas menunjukkan nilai CIPP $(++++)$. Jika dikonversikan ke dalam kuadran prototype Glikman, maka evaluasi program bantuan dana bergulir pada empat koperasi penerima program bantuan dana bergulir di Kabupaten Buleleng Tahun 2014 terletak pada kuadran I (satu) yaitu efektif. Artinya pada dimensi context tergolong efektif, pada dimensi input tergolong efektif, pada dimensi process tergolong efektif, dan pada dimensi product tergolong efektif. Dengan demikian bahwa evaluasi program bantuan dana bergulir pada empat koperasi penerima program bantuan dana bergulir di Kabupaten Buleleng Tahun 2014 tergolong efektif.

\section{Pembahasan}

Berdasarkan hasil penelitian evaluasi program bantuan dana bergulir pada empat koperasi penerima program bantuan dana bergulir di Kabupaten Buleleng Tahun 2014 ditemukan bahwa evaluasi program bantuan dana bergulir pada empat koperasi penerima program bantuan dana bergulir di Kabupaten Buleleng Tahun 2014 berada pada kategori efektif $(++++)$. Temuan studi evaluatif bahwa evaluasi program 
bantuan dana bergulir pada empat koperasi penerima program bantuan dana bergulir di Kabupaten Buleleng Tahun 2014 dikatakan efektif dikarenakan pada dimensi context berada pada kategori efektif (+), dimensi input berada pada kategori efektif $(+)$, dimensi process berada pada kategori efektif $(+)$, dan pada dimensi product berada pada kategori efektif $(+)$.

Pada dimensi context, hasil penelitian menunjukkan bahwa secara umum tampak bahwa dimensi context tergolong efektif seperti pada indikator kebijakan terkait dengan program, tujuan program, harapan dan peluang pengembangan diri sudah dapat mendukung berlangsungnya program bantuan dana bergulir yang diberikan. Indikator yang belum mendukung efektifnya program bantuan dana bergulir yaitu pada indikator kebutuhan. Kebutuhan koperasi tidak dapat terpenuhi karena target permohonan pinjaman bantuan dana bergulir yang diajukan oleh koperasi kepada pemerintah, tidak semua dapat terealisasi seperti pada KUD Dharma Prawerti yang sebelumnya menargetkan permohonan pinjaman modal sebesar $\mathrm{Rp}$ 2.000.000.000,00 namun yang terealisasi sebesar $\mathrm{Rp}$ 1.000.000.000,00, dan KSU Cipta Dharma Sejahtera yang sebelumnya menargetkan permohonan pinjaman modal sebesar $\mathrm{Rp}$ 400.000.000,00 namun yang terealisasi sebesar $\mathrm{Rp}$ 350.000.000,00 sedangkan pada KUD Karma Bumi Amertha dan KUD Tirta Luhur sudah sesuai dengan target permohonan pinjaman. Kebutuhan koperasi merupakan salah satu kunci dalam meningkatkan kemampuan koperasi dalam meningkatkan usahanya. Bantuan dana bergulir yang diberikan harus dapat memenuhi kebutuhan koperasi sehingga dengan adanya program bantuan dana bergulir yang diberikan, koperasi dapat tumbuh dan berkembang menjadi lebih kuat karena koperasi merupakan organisasi ekonomi rakyat yang harus dikembangkan menjadi unit usaha yang kukuh dalam rangka proses demokratisasi ekonomi.

Pada dimensi input, hasil penelitian menunjukkan bahwa secara umum tampak bahwa dimensi input tergolong efektif seperti pada indikator sumber daya manusia, sosialisasi, manajemen, sarana prasarana, dan petunjuk pelaksanaan. Pada indikator yang belum mendukung efektifnya program bantuan dana bergulir yaitu pada indikator dana operasional. Hal ini sejalan antara indikator kebutuhan dengan dana operasional karena jumlah dana yang diberikan oleh pemerintah kepada koperasi tidak sepenuhnya dapat terealisasi sesuai dengan target permohonan pinjaman modal koperasi, seperti pada KUD Dharma Prawerti yang sebelumnya menargetkan permohonan pinjaman modal sebesar Rp 2.000.000.000,00 namun yang terealisasi sebesar $\mathrm{Rp}$ 1.000.000.000,00, dan KSU Cipta Dharma Sejahtera yang sebelumnya menargetkan permohonan pinjaman modal sebesar $\mathrm{Rp} \quad 400.000 .000,00$ namun yang terealisasi sebesar $\mathrm{Rp}$ 350.000.000,00. Dana operasional bersifat sangat penting dalam mengembangkan usaha koperasi. Bantuan dana yang diberikan harus dapat terpenuhi oleh koperasi karena koperasi harus dapat meningkatkan usahanya menjadi lebih maju dan berkembang karena semakin tinggi modal yang dimiliki oleh koperasi dalam menjalankan usahanya, maka semakin tinggi pula koperasi dapat meningkatkan dan mengembangkan usahanya.

Pada dimensi process, hasil penelitian menunjukkan bahwa secara umum tampak bahwa dimensi process tergolong efektif seperti pada indikator perencanaan program, proses seleksi program, penyaluran dana, pemanfaatan dana, dan pengembalian dana. Pada indikator yang belum mendukung efektifnya program bantuan dana bergulir yaitu pada indikator monitoring. Hal ini dikarenakan pelaksanaan pengawasan yang dilakukan oleh pemerintah melalui 
Dinas Koperasi, Perdagangan, dan Perindustrian Kabupaten Buleleng belum sepenuhnya dilaksanakan sepanjang pelaksanaan program bantuan dana bergulir berlangsung dan tidak melakukan evaluasi terhadap program yang telah diberikan. Monitoring mempunyai peranan yang sangat penting dalam berlangsungnya program bantuan dana bergulir yang diberikan oleh pemerintah kepada koperasi. Dengan adanya monitoring dan evaluasi terhadap pelaksanaan program bantuan dana bergulir, pemerintah dapat mengetahui sejauhmana program bantuan dana bergulir dapat berjalan dengan baik.

Pada dimensi product, hasil penelitian menunjukkan bahwa secara umum tampak bahwa dimensi product tergolong efektif dalam mengimplementasikan program bantuan dana bergulir yang diberikan oleh pemerintah kepada empat koperasi tahun 2014. Dari empat parameter yang sudah ditetapkan sebagai acuan keberhasilan program dilihat dari variabel produk, tampaknya semua sudah sesuai dengan harapan bahwa dengan adanya program bantuan dana bergulir yang diberikan, koperasi dapat meningkatkan kemampuan koperasi dalam mengakses sumber pendanaan, koperasi dapat meningkatkan kemampuan koperasi dalam menciptakan nilai tambah atas barang atau jasa, koperasi dapat meningkatkan peran koperasi dalam memperluas kesempatan kerja, dan koperasi dapat meningkatkan peran koperasi dalam mengentaskan kemiskinan.

\section{SIMPULAN DAN SARAN Simpulan}

Berdasarkan analisis data dan temuan penelitian, maka dapat disimpulkan yaitu : Evaluasi program bantuan dana bergulir dilihat dari dimensi context menunjukkan hasil $\sum \mathrm{f}$ $(+)=15>\sum f(-)=5$, atau menghasilkan + (efektif). Dengan demikian, dapat dinyatakan bahwa pada dimensi context evaluasi program bantuan dana bergulir pada empat koperasi penerima program bantuan dana bergulir di Kabupaten Buleleng Tahun 2014 tergolong efektif.

Evaluasi program bantuan dana

bergulir dilihat dari dimensi input menunjukkan hasil $\sum f(+)=11>\sum f(-)$ $=9$, atau menghasilkan + (efektif). Dengan demikian, dapat dinyatakan bahwa pada dimensi input evaluasi program bantuan dana bergulir pada empat koperasi penerima program bantuan dana bergulir di Kabupaten Buleleng Tahun 2014 tergolong efektif.

Evaluasi program bantuan dana bergulir dilihat dari dimensi process menunjukkan hasil $\sum \mathrm{f}(+)=12>\sum \mathrm{f}(-)$ $=8$, atau menghasilkan + (efektif). Dengan demikian, dapat dinyatakan bahwa pada dimensi process evaluasi program bantuan dana bergulir pada empat koperasi penerima program bantuan dana bergulir di Kabupaten Buleleng Tahun 2014 tergolong efektif.

Evaluasi program bantuan dana bergulir dilihat dari dimensi product menunjukkan hasil $\sum f(+)=12>\sum f(-)$ $=8$, atau menghasilkan + (efektif). Dengan demikian, dapat dinyatakan bahwa pada dimensi product evaluasi program bantuan dana bergulir pada empat koperasi penerima program bantuan dana bergulir di Kabupaten Buleleng Tahun 2014 tergolong efektif.

\section{Saran}

Berdasarkan hasil penelitian dan pembahasan serta simpulan yang telah diuraikan sebelumnya, maka saran yang dapat dikemukakan yaitu : bagi Pemerintah Pusat melalui Lembaga Pengelola Bantuan Dana Bergulir (LPDB) selaku pemberi program bantuan dana bergulir kepada koperasi hendaknya dalam pemberian bantuan dana harus dapat memenuhi kebutuhan koperasi terutama dari segi pemberian dananya dengan cara memberikan jumlah pinjaman yang sesuai dengan kebutuhan koperasi, karena bantuan dana yang diberikan oleh pemerintah nantinya akan sepenuhnya digunakan oleh koperasi untuk dapat meningkatkan kemampuannya dalam mengembangkan usaha koperasi sehingga koperasi tidak perlu kembali 
meminjam bantuan dana kepada pihak lain.

Bagi Pemerintah Daerah melalui

Dinas Koperasi, Perdagangan dan Perindustrian Kabupaten Buleleng selaku pihak yang mengawasi berjalannya program bantuan dana bergulir bagi koperasi, dari segi monitoring terhadap keberlangsungan program bantuan dana bergulir yang diberikan kepada koperasi, pihak pengawas harus lebih meningkatkan pengawasannya dan melakukan monitoring sepanjang berlangsungnya program bantuan dana bergulir dan pemerintah harus melaksanakan evaluasi terhadap pelaksanaan program bantuan dana bergulir yang diberikan untuk dapat mengetahui sejauhmana program tersebut dapat berjalan dengan baik dan efektif sehingga koperasi lebih transparans dalam mengelola bantuan dana yang diberikan oleh pemerintah.

Bagi peneliti lain yang berminat untuk mendalami bidang evaluasi program yang diberikan oleh pemerintah, disarankan untuk meengembangkan penelitian ini dengan mengembangkan metode yang sama pada program yang diberikan oleh pemerintah lainnya. Hal ini berguna agar hasilnya lebih maksimal terhadap proses evaluasi program yang diberikan pemerintah.

\section{DAFTAR PUSTAKA}

Ardika, I Nyoman. 2012. Efektivitas Penggunaan Dana Bantuan Operasional Sekolah (BOS) Ditinjau Dari Model CIPP Dalam Kaitannya Dengan Peningkatan Kinerja Sekolah Di SD No. 3 Kerobokan. Tesis Jurusan Administrasi Pendidikan,Program Pascasarjana Universitas Pendidikan Ganesha.

Arikunto, Suharsimi dan Cepi Safrudin Abdul Jabar. 2010. Evaluasi Program Pendidikan. Edisi ke-2. Jakarta: PT Bumi Aksara.

------ 2004. Evaluasi Program Pendidikan. Jakarta: PT Bumi Aksara.
Bungin, Burhan. 2009. Metodologi penelitian kuantitatif. Jakarta: Kencana Prenada Media Group.

Cenik, I Wayan. 2014. Efektivitas Program BOS SMA Di SMA Negeri Kabupaten Karangasem Dalam Rangka Mendukung Pendidikan Menengah Universal. Tesis Jurusan Administrasi Pendidikan, Program Pascasarjana Universitas Pendidikan Ganesha.

Dinas Koperasi, Perdagangan dan Perindustrian Kabupaten Buleleng. 2015. Data Koperasi Penerima Bantuan Dana Bergulir. Buleleng.

Manurung, 2000. Perkoperasian Di Indonesia: "Masalah, Peluang dan Tantangan di Masa Depan". Economics e-journal, 28 Januari 2000.

Mardiasmo. 2009. Akuntansi Sektor Publik. Yogyakarta : Andi.

Marhaeni, 2007. Evaluasi Program Pendidikan. Singaraja: Program Pasca Sarjana Universitas Pendidikan Ganesha.

Munir, 2008. Kurikulum Berbasis Tekhnologi Informasi dan Komunikasi. Bandung: Alfabeta.

Musa, Safuri. 2005. Evaluasi Program: Pembelajaran dan Pemberdayaan Program. Bandung: Y-PIN Indonesia.

Nata, Wirawan. 2002. Cara Mudah memahami Satistik 2. Denpasar: Keraras Emas.

Sitio, Arifin dan Tamba, Halomoan. 2001. Koperasi: Teori dan Praktek. Jakarta: Penerbit Erlangga.

Sugiyono, 2003. Metodelogi Penelitian Bisnis. Bandung: CV. Alfabeta. 
p-ISSN : 2599-1418

e-ISSN : 2599-1426

------ 2010. Metode Penelitian Kuantitatif Kualitatif dan $R \& D$. Bandung: CV. Alfabeta.

Sukardi. 2008. Evaluasi Pendidikan (Prinsip dan Operasionalnya). Yogyakarta: Bumi Aksara.

Tayibnapis, Farida Yusuf. 2000. Evaluasi Program. Jakarta: PT Rineka Cipta.

Umar, Husein. 2005. Metode Penelitian untuk Skripsi dan Tesis Bisnis. Jakarta: PT Raja Grafindo Persada
Jurnal Pendidikan Ekonomi Undiksha Volume 9 No.1 Tahun: 2017
Undang-undang Republik Indonesia Nomor 25 Tahun 1992 tentang Perkoperasian. Surabaya : Arloka

Widiyanti, Ninik dan Y.W.Sunindhia. 2003. Koperasi dan perekonomian Indonesia. Jakarta: PT.Rineka.

Wirawan. 2011. Evaluasi: Teori, Model, Standar, Aplikasi, dan Profesi. Jakarta: PT Rajagrofindo Persada 